Review paper

\title{
PATHOGENESIS, EPIDEMIOLOGY AND VARIANTS OF MELISSOCOCCUS PLUTONIUS (EX WHITE), THE CAUSAL AGENT OF EUROPEAN FOULBROOD
}

\author{
Adrián Ponce de León-Door ${ }^{1,2}$ \\ Gerardo Pérez-Ordóñez² \\ Alejandro Romo-Chacón \\ Claudio Rios-Velasco ${ }^{2}$ \\ José D. J. Órnelas-Paz \\ Paul B. Zamudio-Flores ${ }^{2}$ \\ Carlos H. Acosta-Muñiz ${ }^{2 *}$ \\ 1 Universidad Tecnologíca de la Babícora, Km. 1 S/N, Carretera Soto Maynez-Gómez \\ Farías, C. P. 31963, Namiquipa, Chihuahua, Mexico \\ ${ }^{2}$ Centro de Investigación en Alimentación y Desarrollo A.C., Unidad Cuauhtémoc, Av. \\ Río Conchos S/N, Parque Industrial. C. P. 31570, Apartado Postal 781, Cd. Cuauhté- \\ moc, Chihuahua, Mexico
}

*corresponding author: cacosta@ciad.mx

Received: 17 January 2020; accepted: 27 August 2020

\section{A b s tract}

The bacterium Melissococcus plutonius is the etiologic agent of the European foulbrood (EFB), one of the most harmful bacterial diseases that causes the larvae of bees to have an intestinal infection. Although EFB has been known for more than a century and is practically present in all countries where beekeeping is practiced, the disease has been little studied compared to American foulbrood. Recently, great advances have been made to understand the disease and the interaction between the pathogen and its host. This review summarizes the research and advances to understand the disease. First, the morphological characteristics of $M$. plutonius, the infection process and bacterial development in the gut of the larva are described. Also, the epidemiological distribution of EFB and factors that favor the development of the disease as well as the classification of M. plutonius according its genomic and phenotype characteristics are reported. Finally, the new molecular tools for the study of $M$. plutonius, possible virulence factors in its genome, the issue of current EFB control measures and possible alternatives to the use of antibiotics are addressed.

Keywords: Apis mellifera, European foulbrood disease, Melissococcus plutonius, pathogenesis, virulence

\section{INTRODUCTION}

Honey bees (mainly Apis mellifera) are the most valuable pollinators in the world. They are inexpensive, versatile, and usually, the only solution to guarantee pollination (Morse \& Calderone, 2000). However, their health is impacted by such numerous pathogens as bacteria, viruses, fungi and parasites. The factors involved in bee's health affect sustainable and profitable agriculture, as well as many non-agricultural ecosystems, (Genersch, 2010). One of the most vital bacterial diseases of honey bees in the world is European Foulbrood (EFB) caused by the bacterium Melissococcus plutonius. EFB is generally associated with such secondary bacteria as Enterococcus faecalis, Brevibacillus laterosporus, Bacillus pumilis, Paenibacillus alvei, and Paenibacillus dendritiformis that may lead to a pathogenic effect, but their role in the development of the disease is unclear (Forsgren, et al., 2018). M. plutonius leads to intestinal infection in bee larvae causing death between the fourth and seventh days. Infected larvae 
have an abnormal position inside the brood cell and the color of the larvae changes from pearly white to yellow, then brown and finally, when they decompose to grayish-black (Bailey, 1961). Occasionally, the larvae die after the brood cell is sealed. Present $P$. alvei remains and multiplies in the larvae and sunken opercula can be observed, and these symptoms are possibly confused with American foulbrood (Bailey \& Ball, 1991; Forsgren, 2010). M. plutonius infects European bees $A$. mellifera, Asian bees A. cerana (Singh Rana et al., 2012; Takamatsu et al., 2014) and Himalayan bees $A$. laboriosa (Allen, Ball, \& Underwood, 1990). The etiologic agent of EFB was identified more than a century ago (White, 1912). To understand and treat a disease, the causative agent, mechanisms of infection, and favorable conditions for its development must be identified. This review summarizes recent research on the epidemiology and pathogenesis of M. plutonius, the causative agent of EFB.

\section{Pathogenesis and Epidemiology}

Melissococcus plutonius was first classified as Bacillus pluton (White, 1912) and later as Streptococcus pluton (Bailey, 1957b). However, Bailey, \& Collins (1982) described Melissococcus as a new genus, containing the species Melissococcus pluton based on culture, biochemi- cal and chemical characteristics. The specific epithet 'pluton' was corrected to plutonius by Dicks, Endo, \& Van Reenen (2014) and Trüper \& de'Clari (1998). M. plutonius is a Gram-positive cocci lanceolate oval-shaped, non-spore-forming bacteria, with an approximate size of $0.5 \times 1.0$ $\mu \mathrm{m}$ (Fig. 1), that is found individually, in pairs or chains of various lengths (Forsgren, 2010; Forsgren et al., 2013). The bacteria only affect the larval stages of bees (Bailey \& Collins, 1982). The infection begins with the consumption of contaminated food during the early larval stage, when the larvae are exclusively fed with royal jelly (RJ), a mixture of secretions from the hypopharyngeal and mandibular glands of young worker bees (Snodgrass, 1925).

Royal jelly (RJ) has high antimicrobial activity (Melliou \& Chinou, 2014) due to proteins like major royal jelly protein 1 (MRJP1) containing jelleins 1, 2 and 3, which inhibit bacterial, yeast and fungus growth (Brudzynski \& Sjaarda, 2015; Fontana et al., 2004). Recently Vezeteu et al. (2017), showed how MRJP1 can inhibit the development of bacteria associated with EFB, including M. plutonius. MRJP2 has an antibacterial effect against $P$. larvae (Bíliková, Wu, \& Šimúth, 2001) and the enzyme glucose oxidase, which is essential to inhibiting microbial development in larval foods and honey (Ohashi, Natori, \& Kubo,

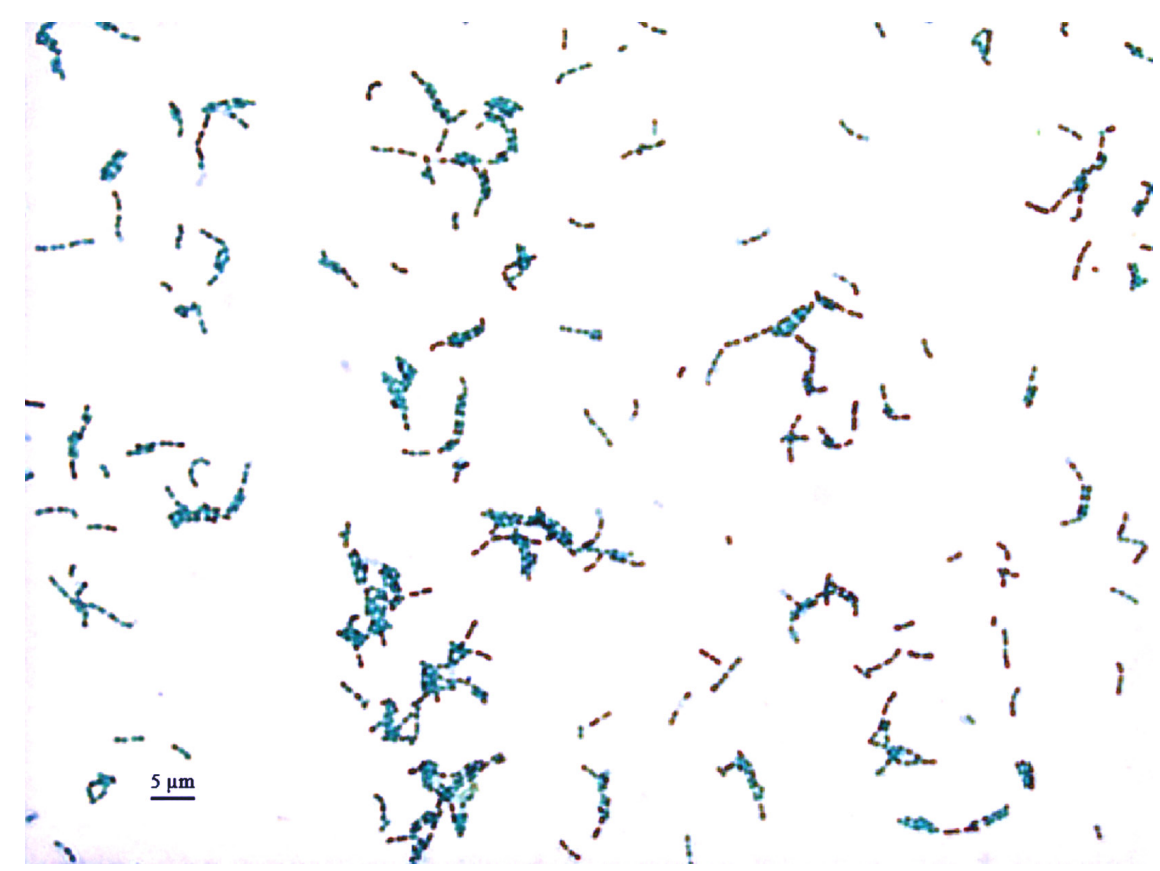

Fig. 1. Gram staining of Melissococcus plutonius strain ATCC 35311, Cultivated under anaerobic conditions in SBK medium for 5 days at $36^{\circ} \mathrm{C}$. 
1999; Sano et al., 2004). On the other hand, such non-protein components as 10-hydroxy-2-decenoic acid (10-HDA) have demonstrated antipathogenic activity. Šedivá et al. (2018) showed that 10-HDA contributes to the inhibition of $P$. larvae, and Yang, Li, \& Wang (2015) proposed that it is a broad-spectrum antimicrobial agent that inhibits multiple pathogenic bacteria. However, despite the RJ antimicrobial activity, M. plutonius can survive and infect honey bee larvae through it (Takamatsu et al., 2017).

Studies show that after ingestion, M. plutonius reaches the middle intestine of the larvae, where it begins to multiply until it almost occupies the intestinal lumen without crossing the peritrophic membrane (Tarr, 1938). White (1912) determined that M. plutonius grows only in the food mass within the peritrophic matrix, killing its host before any bacteria associated with EFB succeeds in invading the larval tissues. Derived from this, Bailey (1983) suggested that the pathogenic effect was due to nutrient competition between the larva and the pathogen, resulting in starvation of the larvae. McKee, Goodman, \& Hornitzky (2004) suggested that the death of the larvae may be the result of such additional pathogenic mechanisms as peritrophic matrix invasion and penetration into other host tissues. However, Takamatsu, Sato, \& Yoshiyama (2016) refuted this theory inferring that the presence of substances produced by M. plutonius can diffuse into larval tissues during the infection, but these substances and other virulence factors remains unidentified. Only 100 to 200 bacteria cells are required to cause EFB (Bailey, 1960; McKee et al., 2004), and once the infection is established, the larvae can die before the brood cell is covered. In this case, larvae are expelled from the colony or may die after the brood cell is covered where the sunken upper wax layer is observed (Fig. 2-5c). Sometimes, the larvae survive the infection, however, pupation is delayed (McKee et al., 2004), and smaller adults emerge (Bailey, 1959b), which can transmit the bacteria (Fig. 2-6b).

Melissococcus plutonius multiplies only within the larval intestine of the honey bee. The persistence of the pathogen in the hive depends on the infected larvae's survival, which deposits the bacteria along with their feces

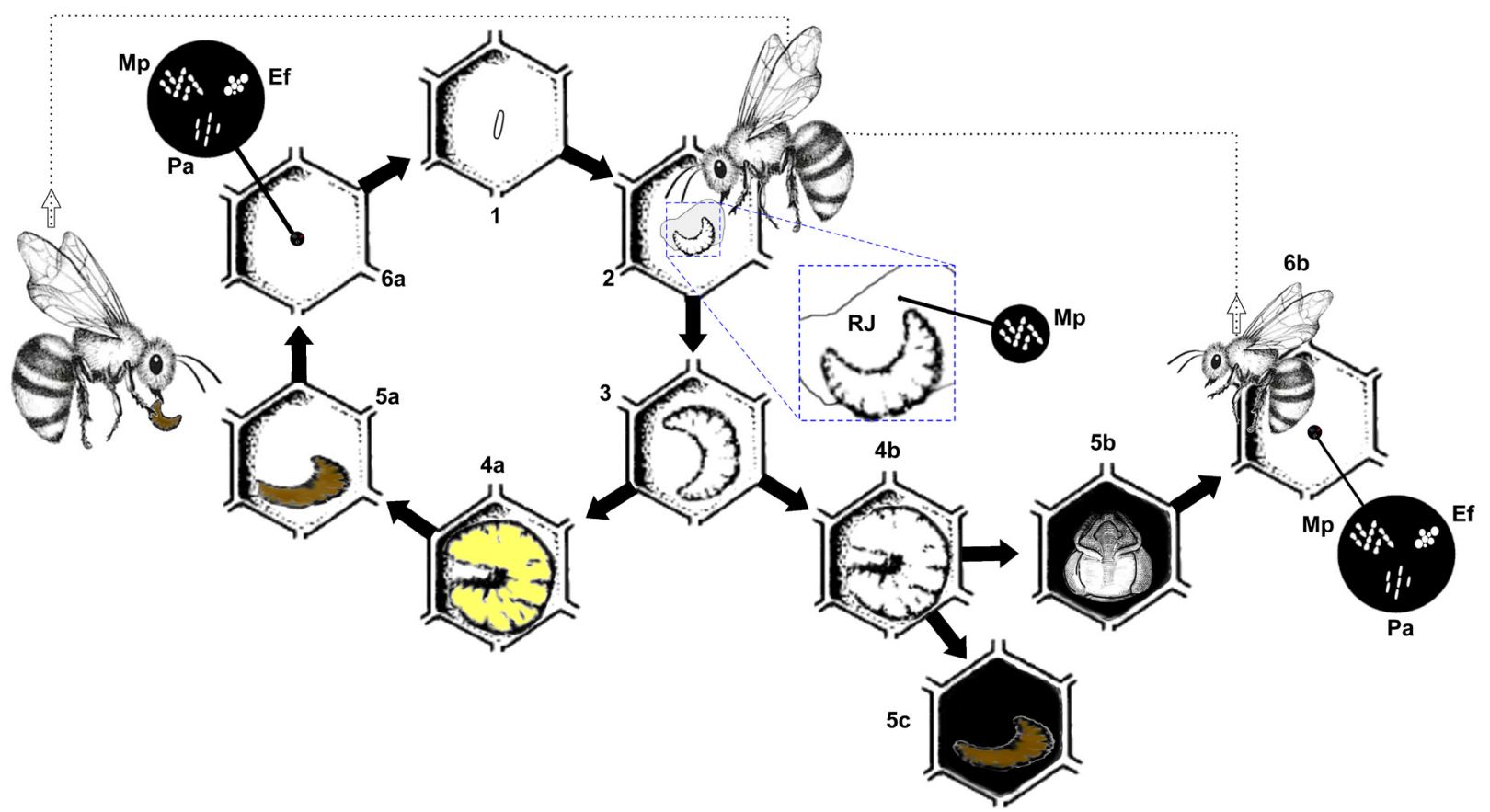

Fig. 2. Melissococcus plutonius infection cycle 1. egg, 2. Ingestion of M. plutonius (Mp) in the royal jelly (RJ). 3. Proliferation of M. plutonius in the intestine, 4a. Manifestation of EFB symptoms, 4b Larvae without EFB symptoms, 5a. Death of larvae, scale formation and brood removal by worker bees, 5 b. Sealing cell and slow pupae development, $5 c$. Death of larva after cell was seal, $6 a$. Cell with M. plutonius and secondary agents, 6b. Emergence of smaller adults carrying M. plutonius and cells with M. plutonius and secondary agents. Adapted from Bailey \& Ball (1991). 
in the brood cell when they pupate (Fig. 2-6a, 6b). M. plutonius stay viable in the brood cell, surviving for several years (Bailey, 1959a). A large number of bacterial cells die during this time, but the remaining bacteria can infect other larvae. If the infected larva dies before it becomes a pupa, the worker bees eliminate the infected larvae (Fig. 2-5a), reducing the number of bacteria that serve as a source of inoculum. Nevertheless, worker bees will subsequently feed new larvae causing the transmission of the bacteria (Fig. 2-2). The infection is not always fatal, and M. plutonius can be present in larvae and pupae without any clinical symptoms (Fig. 24b) (Forsgren et al., 2005) due to the different degrees of virulence.

Adult worker bees responsible for removing diseased larvae from the hive have higher M.plutonius loads than nectar and pollen-collecting bees because workers bees are in direct contact with the infected brood that contains large amounts of the bacteria (Roetschi et al., 2008). Adult bees act as carriers of the bacteria inside the colony, between colonies and between apiaries. More than a third of healthy colonies in an apiary can maintain adult bees carrying the bacteria due to the proximity to other diseased apiaries (Belloy et al., 2007). In Switzerland, a high density of colonies and hives have been shown to promote the transmission of EFB (von Büren et al., 2019). Additionally, Abrol (2013) and Forsgren (2010) suggested that the robbing of honey and drifting bees contributed to the spread of the bacteria between colonies and apiaries, but in contrast Goodwin, Perry, \& Houten (1994) suggested that the drift of bees is not an important to the spread of AFB. However, it is not clear how EFB spreads reapidly, but such beekeeping practices as the exchange of contaminated combs, poor equipment sanitation and poor diet may contribute to it (Fig. 3) (Belloy et al., 2007; Hornitzky \& Smith, 1998; McKee et al., 2003).

Bacteria of the genus Enterococcus are found in a variety of soil, water, and plants habitats (Forsgren, 2010). Martzy et al. (2017) mentioned the possible presence of M. plutonius in water, but the qPCR and loop-mediated isothermal amplification (LAMP) tests which they utilized are not specific, and M. plutonius was co-detected with Tetragenococcus halophilus, Vagococcus fluvialis and Enterococcus faecalis. This suggests that water could be a reservoir for M. plutonius, but more studies are required.

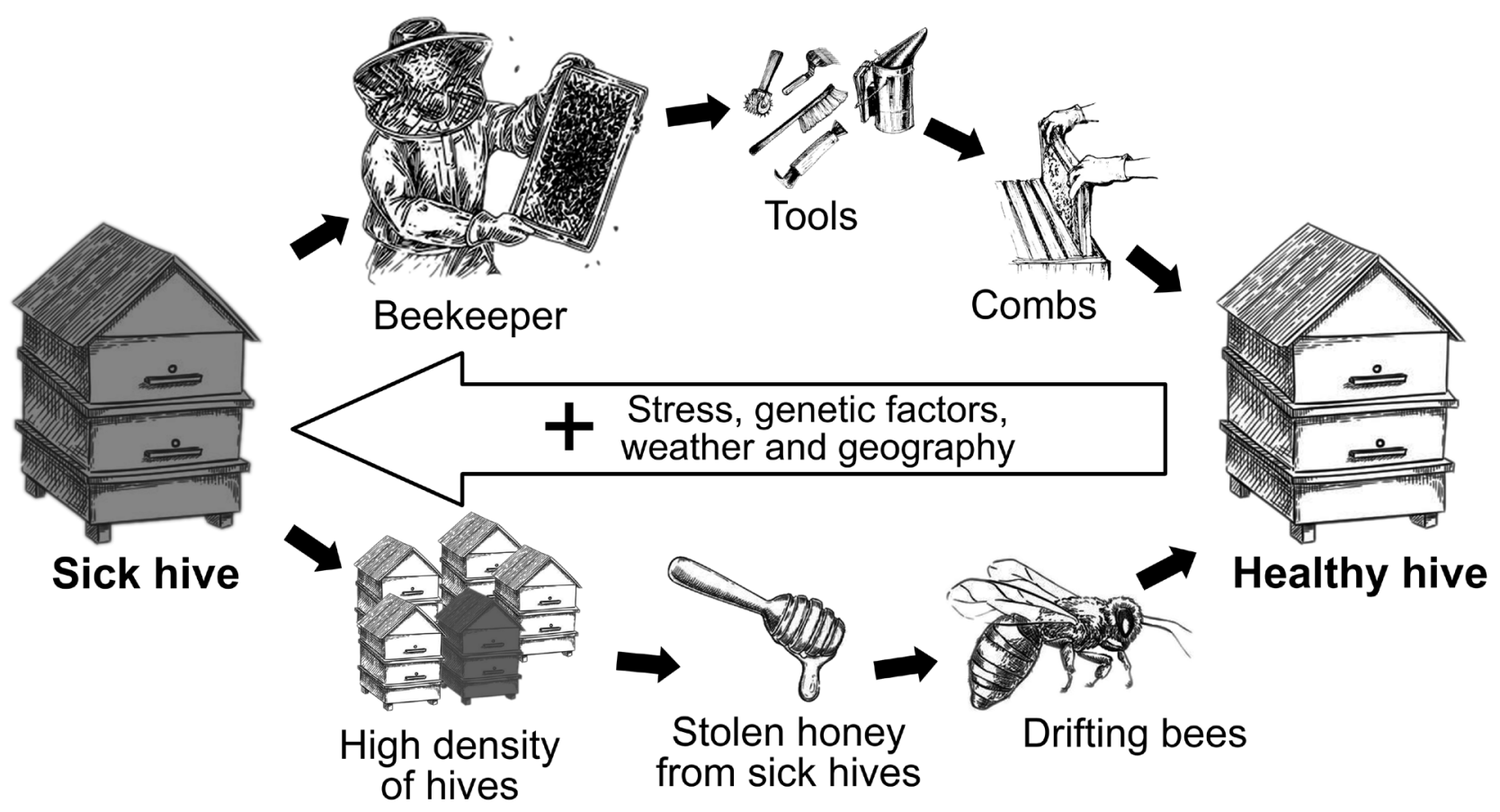

Fig. 3. Dissemination model of European foulbrood. 


\section{ง. APPC. SCLI. VOL. 64 N NO. 220202}

Disease outbreaks appear to be related to colony stress conditions - lack of food, water, genetic factors, climate and geography (Budge et al., 2014; Forsgren, 2010). EFB can be manifested for a short period, usually during summer or early spring (Bailey \& Ball, 1991). Unexpected outbreaks of the disease have been observed followed by a spontaneous recovery a few weeks later. Severely infected colonies that move from infected endemic areas to diseasefree areas can recover spontaneously (Bailey, 1961; Bailey \& Locher, 1968).

The incidence of EFB has been reported in five continents and by 2019 only Nicaragua and Mozambique, of the 180 member countries of the World Organization for Animal Health (OIE), had never reported the disease (OIE, 2019). There have been occasional seasonal outbreaks of EFB in many countries (Bailey, 1961; Forsgren et al., 2013). However, in Switzerland, the incidence of EFB has increased dramatically since 1990, in the United Kingdom, it has become the most widespread brood bacterial disease and in Norway an outbreak was reported in 2010 after a thirty-year absence (Forsgren et al., 2018). Geographically, the disease seems to vary in severity, from relatively benign in some areas to very severe in others (Dahle, Sørum, \& Weidemann, 2011; Wilkins, Brown, \& Cuthbertson, 2007). Virulence tests on individual larvae using exposure bioassays show that M.plutonius strains collected in different European geographic locations vary in their morbidity (Charriere, Kilchenmann, \& Roetschi, 2011).

Several studies mention the molecular detection of M. plutonius in such countries as Mexico, Turkey, India, Saudi Arabia, Spain and Colombia (Ansari et al., 2017; Borum et al., 2015; de León-Door et al., 2018; Garrido-Bailón et al., 2013; Singh Rana et al., 2012; Tibatá et al., 2018). For an epidemiological study, isolated strains should be classified. The chosen method to classify a specific pathogenic species must meet several criteria. All strains of the species must be classified with the chosen method, which must have a high power of differentiation and the results must be reproducible within a laboratory and between laboratories for the construction of reliable databases. Classification methods based on the phenotype have several deficiencies, especially with the applicability to all members of a species. Tenover et al. (1995) established classification methods based on the microbial genotype or a particular DNA sequence. For the epidemiological study of $E F B$, Haynes et al. (2013) designed a classification system of Multi-locus sequence typing (MLST), based on the locus used for typing of Enterococcus faecalis (Ruiz-Garbajosa et al., 2006) and Enterococcus faecium (Homan et al., 2002). This scheme allowed the analysis of $381 \mathrm{M}$. plutonius isolates from different countries, achieving the identification of thirty-two sequences types, which were grouped into three genetically distinct groups, called clonal complexes (CCs). Budge et al. (2014), created the public database, https://pubmlst.org/mplutonius/, where the epidemiological information of M. plutonius has been uploaded.

\section{Genotypes and virulence}

Melissococcus plutonius was initially described by White (1912) and characterized by Bailey (1957b) as a demanding organism, which requires anaerobic or microaerophilic conditions for growth. Furthermore, its isolation and support requires the addition of potassium phosphate to the culture medium (Bailey \& Collins, 1982). Early morphological, physiological, immunological and genetic studies suggested that the M. plutonius species was homogeneous (Allen \& Ball, 1993; Djordjevic et al., 1999), and several reports mention that $M$. plutonius loses its virulence rapidly when it is subcultured in vitro. Due to this situation, the infection of bee larvae with artificially cultivated M. plutonius was challenging, and Giersch, Barchia, \& Hornitzky (2010) reported that a high dose of it in addition to a secondary inoculation with Paenibacillus alveicaused high larval mortality. However, high doses of M. plutonius used, since Lewkowski \& Erler (2019) showed that additional infections with possible secondary invaders do not increase larval mortality. On the other hand, McKee et al. (2004) and Bailey (1957a) failed to produce EFB 
in artificially bred larvae with pure M. plutonius cultures. Consequently, studies to determine the etiology of EFB were complicated.

Arai et al. (2012) called M. plutonius variants present in Japan "atypical" because they did not match the phenotypic characteristics originally described for this species. The atypical strains do not require high concentrations of potassium phosphate, grow even in the presence of oxygen, are positive for $\beta$-glucosidase activity and produce acid from L-arabinose, D-cellobiose, and salicin. The analysis of atypical strains by pulsed-field gel electrophoresis showed genetic differences. Additionally, these strains showed a high virulence, killing all infected larvae in a period of $5 \mathrm{~d}$, while the typical strains did not show mortality.

Haynes et al. (2013) used the sequences of argE, $g a l K$, purR, and $g b p B$ genes to develop a higher resolution classification scheme using MLST. This allowed the identification of thirty-two sequence types (STs), grouped into three clonal complexes (CCs), in which Japanese atypical isolates belonged to CC12 and typical strains to CC3 and CC13. The studies conducted by Budge et al. (2014), Takamatsu et al. (2014) and de León-Door et al. (2018), showed that these CCs were widely distributed throughout the world, even in Asian bees Apis ceranae. Some isolates from Brazil, United Kingdom, USA and the Netherlands have been classified inside the CC12 where atypical strains are found. An analysis of the database designed by Budge et al. (2014) (https://pubmlst.org/mplutonius/) showed that from the 381 isolates reported 66\% correspond to CC3, $20 \%$ to CC12 and the remaining $14 \%$ to CC13 (Consulted on April 12, 2020).

In the study conducted by Nakamura et al. (2016), the virulence of the different CCs was tested. CC12 showed the highest virulence, killing more than $90 \%$ of infected larvae before pupation, similar to the report by Arai et al. (2012). However, CC3 belonged to the strains reported as typical and showed a higher virulence than reported by Arai et al. (2012), killing approximately $60 \%$ of infected larvae. For its part, CC13 showed no virulence, being similar to the mortality in the control larvae.
Similar results were shown by Lewkowski and Erler (2019), where the CC3 strain caused greater mortality than the CC13 strains, and all cases of CC13 lethality are similar to the control. Additionally, different genetic backgrounds contribute significantly to the course of the disease. Although not all CCs caused the death of infected larvae, an increase in the number of $M$. plutonius bacteria from the three CCs was observed during the six days post-infection (Nakamura et al., 2016), which indicates that even when $\mathrm{CC} 13$ does not cause death, it can colonize the larva's intestine. However, its effect on adult bees remains unknown.

The CC12 strains show the highest virulence in vitro at the individual level, but this is inconsistent with the number of isolates reported. Budge et al. (2014) claimed that CC3 is the most virulent at the colony level, followed by CC12 and CC13. These results suggest the physiological advantage of the CC3 strains for their survival and pathogenic potential. Takamatsu et al. (2017) mentioned that CC3 strains can survive and even proliferate in a concentration of $50 \%$ RJ. On the other hand, CC13 was the most susceptible to RJ components, because its number of viable bacterial cells decreased by $99 \%$ while the number of CC12 strains' viable bacterial cells decreased by only $80 \%$ at the same concentration of RJ. Arai et al. (2014) concluded that larvae infected with strains of CC12 develop EFB rapidly and are expelled from the colony by worker bees before the disease is evident. For this reason, fewer isolates of CC12 have been reported.

\section{Genomic analysis}

The lack of molecular tools challenges the studies on $M$. plutonius. To improve this situation, Takamatsu et al. (2013) developed a gene expression vector, (pMX2) for gene complementation and an electroporation protocol for M. plutonius. They observed how mutations in genes that encode for the $\mathrm{Na}^{+} / \mathrm{H}^{+}$antiporter and cation transport ATPase are involved in the potassium requirement for the growth of typical strains of M. plutonius. Based on these results, Arai et al. (2014) developed a duplex 
PCR, selecting $\mathrm{Na}^{+} / \mathrm{H}^{+}$antiporter gene and Fur family transcriptional regulator gene as targets for the detection of typical and atypical strains, respectively.

Takamatsu et al. (2015) designed a gene inactivation system in $M$. plutonius, through the use of a pSET6s thermosensitive plasmid vector, originally used for the construction of deletion mutants in Streptococcus suis (Takamatsu, Osaki, \& Sekizaki, 2001). A non-functional srtA mutated gene was added to the pSET6, and after recombination, sortase $A$ activity in $M$. plutonius was suppressed. However, to verify if this gene inactivation system is specific, it is necessary to determine if the phenotypic changes observed in the mutant strains are caused by the elimination of the target genes, by carefully genetic analyses. The combination of PSET6s and pMX2 could be a useful genetic tool for future molecular analyzes in M. plutonius.

Djukic et al. (2018) conducted a comparative genome analysis of fourteen strains of $M$. plutonius, including the already reported genome of the reference strain M. plutonius ATCC 35311 (Okumura et al., 2011), belonging to CC13 (Nonvirulent), and the genome of the Japanese atypical strain M. plutonius DAT561, (Okumura et al., 2012; Okumura, Takamatsu, \& Okura, 2018) belonging to CC12 (highly virulent). Their observations show that genomes exhibited sizes ranging from 2.021 to $2.101 \mathrm{Mbp}$ and included 1,595 to 1,686 genes encoding proteins. Bioinformatics analysis revealed the following genes and proteins that could play a role in the pathogenesis of EFB: putative bacteriocins, cell surface-associated proteins, adhesion, and enterococcal polysaccharide antigen, an epsilon toxin, proteolytic enzymes and capsule associated proteins.

Typical strains belonging to CC13 lack such important virulence factors as tyrosine decarboxylase, endo-alpha-N-acetylgalactosaminidase and a toxin as compared to CC3 and CC12 (Djukic et al., 2018). In addition, plasmid pMP19 carried by the strains of CC12 and CC3 (Okumura, Takamatsu, \& Okura, 2019), can confer additional advantages as compared to strains without the plasmid. However, this plasmid does not remain stable during in vitro propagation and the association of pMP19 with virulence is not clear since this plasmid has also been reported in strains of the three CCs (Takamatsu et al., 2017).

The advantage of atypical CC12 strains could be due to rapid nutrient consumption. The DAT561 strain uses several carbohydrates as a source of energy through glycolysis, the pentose phosphate pathway, ED-pathway and sugar interconversions. Also, the production of virulence-related molecules could favor the rapid death of larvae infected with CC12 strains (Djukic et al., 2018). However, for the verification of these virulence factors, infection studies with fully characterized strains are required to predict a difference in virulence between strains of the different CCs of M. plutonius. Another factor is the genetic variability of the host, whose origin has been observed to strongly influence the mortality of bees infected with $M$. plutonius (Lewkowski \& Erler, 2019). Additionally, the results presented by Tibatá et al. (2018) are consistent with the appreciation that Africanized hybrids are more resistant to diseases.

\section{EFB control}

Before focusing on the treatment of EFB, it is worth mentioning that the best form of disease control is prevention. Beekeepers must maintain proper sanitation practices to prevent the spread of M. plutonius. The equipment must be disinfected correctly before being stored, reused or moved from one colony to another (Arbia \& Babbay, B., 2011). All combs should be inspected for signs of diseased brood when new nucs or full-size colonies are purchased. Upon detection of diseased colonies, a quarantine strategy should be followed (Locke, Low, \& Forsgren, 2019). Frequently replacing queens with those that promote hygienic behavior results in more offspring of workers that remove diseased larvae from the hive more efficiently. Additionally, racks should be replaced annually and exchange between hives avoided (Flores, Spivak, \& Gutiérrez, 2005; Spivak et al., 2003). In addition, providing enough food prevents the robbing of honey and stimulates the queen's posture to produce a greater number of bees 
for diseased brood removal (Bailey \& Ball, 1991; Gochnauer, Furgala, \& Shimanuki, 1975). Weak colonies with less prolific queens are more susceptible to EFB. The death of many larvae result in more contaminated food for the remaining larvae, causing colony collapse (Bailey \& Ball, 1991).

There have been few studies on control measures for EFB. Oxytetracycline hydrochloride (OTC), a bacteriostatic antibiotic used in many countries, inhibits the multiplication of M. plutonius. Since the 1950s, beekeepers have used this antibiotic for the prevention of EFB and American foulbrood (AFB) (Moeller, 1978). However, in AFB, it has caused the emergence of antibiotic resistant Paenibacillus larvaestrains in different regions of the world (Genersch, 2010). The most recent reports in the United Kingdom and Australia evaluated the resistance and susceptibility of M. plutonius to OTC (Hornitzky \& Smith, 1999; Waite et al., 2003), but new largescale studies are needed to determine if the bacteria are still susceptible to the antibiotic.

As an alternative to OTC treatment, the shook swarm method is proposed, in which adult bees are changed to new hives and the combs with sick brood are eliminated. Budge et al. (2010) mention that this control method has an efficacy similar to the use of antibiotics. On the other hand, Waite et al. (2003) suggest that the combination of the shook swarm method and the use of antibiotics reduces the recurrence of the disease at the colony level. However, the shook swarm method was subsequently recommended without the use of antibiotics for the control of EFB, since the disease's clinical signs are only suppressed with bacteriostatic antibiotics and beekeepers unconsciously spread the infection between the colonies (Thompson et al., 2005). Nevertheless, adult bees present in infected hives, especially those in contact with the young, have high loads of $M$. plutonius, and therefore the shook swarm method is probably not as effective, (Belloy et al., 2007; Roetschi et al., 2008), since adult bees act as a vector for the dissemination of M. plutonius. In Switzerland, the sanitation procedure is based only on swarm shaking, due to EU antibiotic restrictions.
Therefore colonies with clinical symptoms are destroyed, but the sanitation procedure is not enough to prevent new outbreaks of EFB in the same hives the following year (Roetschi et al., 2008).

Doughty, Luck \& Goodman (2004) identified ampicillin and amoxicillin, beta-lactam antibiotics, as candidates for the control of EFB. However, these antibiotics are currently used to fight different infections in humans, and the routine use of antibiotics in animal feed, as documented, contributes to the generation of resistant bacteria, a concern to human health leading to a greater public health concern (Cota-Rubio et al., 2014). In addition, bacteriostatic antibiotics only suppress clinical symptoms but do not cure the disease, leading to chemical residues persisting in honey, affecting their quality and safety for human consumption (Martel et al., 2006). Next, antibiotics can affect the vitality and longevity of bees (Peng et al., 1992). Bacterial resistance in M. plutonius has not been reported yet, but in such beekeeping pathogens as $P$. larvae it has become widespread (Evans, 2003), and therefore, alternatives to the use of chemical treatments must be found.

Antagonistic microorganisms have been proposed as a potential alternative to the treatment of EFB. Lactic acid bacteria (LAB) added to the food of the larvae exposed to M.plutonius, was noted to decrease the number of larvae that succumb to the infection (Vásquez et al., 2012). Wu et al. (2014) showed how Bacillus subtilis exhibited inhibitory activity in vitro against M. plutonius. In addition, in vivo feeding trials revealed that the mortality of infected larvae decreased. On the other hand, Killer et al. (2014) reported a new taxon called Lactobacillus apis sp. with the ability to inhibit the growth of M. plutonius. However, the use of these microorganisms presents challenges, since dosing, timing, duration and the microbiological safety of hive products require optimization for the application of these treatments.

Tea tree oil nanoparticles (Santos et al., 2014), Malva sylvestris oil (Cecotti et al., 2016), aqueous and ethanolic extracts of Cinnamomum spp. and Persian salvadora (Hashish et al., 
2016), macelignan and corosolic acid (Kim et al., 2018), terpenes of Thymus vulgaris (Wiese et al., 2018), among others, have been shown to have significant antibacterial effects against M.plutonius. The use of extracts and essential oils for integrated EFB treatment is promising and stimulates the search for other bioactive plant phytochemicals with bactericidal capacity and low toxicity for bees. Currently, the use of bacteriophages for the treatment of EFB shows promising results in many fields (Vandamme \& Mortelmans, 2019). In beekeeping, it has been used successfully for the control of AFB (Brady et al., 2017; Yost, Tsourkas, \& Amy, 2016). However, the isolation of bacteriophages of M.plutonius could be challenging since the cultivation of $M$. plutonius has been described as difficult (Allen \& Ball, 1993).

\section{CONCLUSIONS}

The objective of this review was to present the new advances and pathogenesis of M. plutonius. An essential step has been the identification of variants of $M$. plutonius that maintain their virulence. The MLST has enabled the differentiation of strains and the database will augment our understanding of the global epidemiology of EFB. It is understood how M. plutonius behaves in the early stages of infection, but most infectious process stages are still not clearly explained. The complete genomic sequences allowed the identification of putative virulence factors, probably used by $M$. plutonius during pathogenesis. Additionally, the new genomic tools available for the manipulation of $M$. plutonius will allow a better understanding of these processes at the molecular level. However, more studies are vital to understanding the complex interactions between M. plutonius and honey bee larvae.

Although multiple efforts have been conducted to develop sustainable treatment strategies, progress is limited. The treatment of infected hives with new antibiotics will remain problematic, due to the health risks associated with antibiotic use and the increased awareness to limit antibiotic use in animal production. Recently, this is revealed in the implementation of stricter regulations on the prophylactic use of antibiotics and the presence of residues in bee products. Overall, for the increased sustainable development of the beekeeping industry, new strategies are required to control such bacterial infections as EFB.

\section{REFERENCES}

Abrol, D. (2013). Beekeeping: a compressive guide to bees and beekeeping. Scientific Publishers.

Allen, M., \& Ball, B. (1993). The cultural characteristics and serological relationships of isolates of Melissococcus pluton. Journal of Apicultural Research, 32(2), 80-88. http://dx.doi.org/10.1080/00218839. 1993.11101291

Allen, M., Ball, B., \& Underwood, B. (1990). An isolate of Melissococcus pluton from Apis laboriosa. Journal of Invertebrate Pathology, 55, 439-440. https://doi. org/10.1016/0022-2011(90)90090-S

Ansari, M. J., Al-Ghamdi, A., Nuru, A., Ahmed, A. M., Ayaad, T. H., Al-Qarni, A., ... Al-Waili, N. (2017). Survey and molecular detection of Melissococcus plutonius, the causative agent of European Foulbrood in honeybees in Saudi Arabia. Saudi Journal of Biological Sciences, 24(6), 1327-1335. https://doi.org/10.1016/j. sjbs.2016.10.012

Arai, R., Miyoshi-Akiyama, T., Okumura, K., Morinaga, Y., Wu, M., Sugimura, Y., ... Takamatsu, D. (2014). Development of duplex PCR assay for detection and differentiation of typical and atypical Melissococcus plutonius strains. Journal of Veterinary Medical Science, 76(4), 491-498. https://doi.org/10.1292/ jvms.13-0386

Arai, R., Tominaga, K., Wu, M., Okura, M., Ito, K., Okamura, N., ... Yoshiyama, M. (2012). Diversity of Melissococcus plutonius from honeybee larvae in Japan and experimental reproduction of European foulbrood with cultured atypical isolates. PLOS ONE, 73), e33708. https://doi.org/10.1371/journal.pone.0033708

Arbia, A., \& Babbay, B. (2011). Management strategies of honey bee diseases. Journal of Entomology, 


\section{8(1), 1-15. http://dx.doi.org/10.3923/je.2011.1.15}

Bailey, L. (1957a). The cause of European foul brood. Bee World, 38(4), 85-89. https://doi.org/10.1080/00 $05772 \times .1957 .11094983$

Bailey, L. (1957b). The isolation and cultural characteristics of Streptococcus p/uton and further observations on Bacterium eurydice. Microbiology, 171), 39-48. https://doi.org/10.1099/00221287-17-1-39

Bailey, L. (1959a). An improved method for the isolation of Streptococcus pluton, and observations on its distribution and ecology. Journal of Insect Pathology, 7(1), 80-85.

Bailey, L. (1959b). Recent research on the natural history of European foul brood disease. Bee World, 403), 66-70. https://doi.org/10.1080/000577 2X.1959.11096701

Bailey, L. (1960). The epizootiology of European foulbrood of the larval honey bee, Apis mellifera Linnaeus.

Bailey, L. (1961). European foulbrood. American Bee Journal, 101, 89-92.

Bailey, L. (1983). Melissococcus pluton, the cause of European foulbrood of honey bees (Apis spp.). Journal of Applied Microbiology, 55(1), 65-69. https://doi. org/10.1111/j.1365-2672.1983.tb02648.x

Bailey, L., \& Ball, B. (1991). 4. BACTERIA Honey bee pathology (Second ed., pp. 35-52): Academic Press.

Bailey, L., \& Collins, M. (1982). Reclassification of 'Streptococcus pluton'(White) in a new genus Melissococcus, as Melissococcus pluton nom. rev.; comb. nov. Journal of Applied Microbiology, 53(2), 215-217. https://doi.org/10.1111/j.1365-2672.1982.tb04679.x

Bailey, L., \& Locher, N. (1968). Experiments on the etiology of European foul brood of the honeybee. Journal of Apicultural Research, 72$),$ 103-107. https://doi.org/10.1080/00218839.1968.11100197

Belloy, L., Imdorf, A., Fries, l., Forsgren, E., Berthoud, H.,
Kuhn, R., \& Charrière, J.-D. (2007). Spatial distribution of Melissococcus plutonius in adult honey bees collected from apiaries and colonies with and without symptoms of European foulbrood. Apidologie, 38(2), 136-140. https://doi.org/10.1051/apido:2006069

Biliková, K., Wu, G., \& Šimúth, J. (2001). Isolation of a peptide fraction from honeybee royal jelly as a potential antifoulbrood factor. Apidologie, 32(3), 275283. https://doi.org/10.1051/apido:2001129

Borum, A. E., Özakin, C., Günes, E., Aydin, L., Ülgen, M., \& Cakmak, I. (2015). The investigation by PCR and culture methods of Foulbrood diseases in honey bees in South Marmara region. Kafkas Üniversitesi Veteriner Fakültesi Dergisi, 27(1). https://doi.org/10.9775/ kvfd.2014.11873

Brady, T. S., Merrill, B. D., Hilton, J. A., Payne, A. M., Stephenson, M. B., \& Hope, S. (2017). Bacteriophages as an alternative to conventional antibiotic use for the prevention or treatment of Paenibacillus larvae in honeybee hives. Journal of Invertebrate Pathology, 150, 94-100. https://doi.org/10.1016/j. jip.2017.09.010

Brudzynski, K., \& Sjaarda, C. (2015). Honey glycoproteins containing antimicrobial peptides, Jelleins of the Major Royal Jelly Protein 1, are responsible for the cell wall lytic and bactericidal activities of honey. PLOS ONE, 1944). DOl:10.1371/journal.pone.0120238

Budge, G. E., Barrett, B., Jones, B., Pietravalle, S., Marris, G., Chantawannakul, P.., ... Brown, M. A. (2010). The occurrence of Melissococcus plutonius in healthy colonies of Apis mellifera and the efficacy of European foulbrood control measures. Journal of Invertebrate Pathology, 105(2), 164-170. https://doi. org/10.1016/j.jip.2010.06.004

Budge, G. E., Shirley, M. D., Jones, B., Quill, E., Tomkies, V., Feil, E. ... ... Haynes, E. G. (2014). Molecular epidemiology and population structure of the honey bee brood pathogen Melissococcus plutonius. The ISME Journal, 8(8), 1588. https://doi.org/10.1038/ismej.2014.20

Cecotti, R., Bergomi, P., Carpana, E., \& Tava, A. (2016). 


\section{Ј. APIC. SCLI. VOL. 64 NO. 2 2020}

Chemical characterization of the volatiles of leaves and flowers from cultivated Malvasylvestrisvar. mauritiana and their antimicrobial activity against the aetiological agents of the European and American foulbrood of honeybees (Apis mellifera). Natural product communications, 17(10), 1934578X1601101026. https://doi.org/10.1177/1934578x1601101026

Cota-Rubio, E., Hurtado-Ayala, L., Pérez-Morales, E., \& Alcántara-Jurado, L. (2014). Resistencia a antibióticos de cepas bacterianas aisladas de animales destinados al consumo humano. RelbCi, 7(1), 75-85.

Charriere, J., Kilchenmann, V., \& Roetschi, A. (2011). Virulence of different Melissococcus plutonius strains on larvae tested by an in vitro larval test. Paper presented at the Proceedings of the 42nd International Apicultural Congress, Buenos Aires, Argentina. p.

Dahle, B., Sørum, H., \& Weidemann, J. (2011). European foulbrood in Norway: How to deal with a major outbreak after 30 years absence. Paper presented at the Proceedings of the COLOSS Workshop: The Future of Brood Disease Research-Guidelines, Methods and Development: Copenhagen, p8.

de León-Door, A. P., Romo-Chacón, A., Rios-Velasco, C., Zamudio-Flores, P. B., de Jesús Ornelas-Paz, J., \& Acosta-Muñiz, C. H. (2018). Prevalence, typing and phylogenetic analysis of Melissococcus plutonius strains from bee colonies of the State of Chihuahua, Mexico. Journal of Invertebrate Pathology, 159, 71 77. https://doi.org/10.1016/j.jip.2018.10.006

Dicks, L. M., Endo, A., \& Van Reenen, C. A. (2014). Minor genera of the Enterococcaceae (Catellicoccus, Melissococcus and Pilibacter). Lactic Acid Bacteria: Biodiversity and Taxonomy, 239-243. https://doi. org/10.1002/9781118655252.ch18

Djordjevic, S. P., Smith, L. A., Forbes, W. A., \& Hornitzky, M. A. (1999). Geographically diverse Australian isolates of Melissococcus pluton exhibit minimal genotypic diversity by restriction endonuclease analysis. FEMS Microbiology Letters, 173(2), 311-318. https:// doi.org/10.1111/j.1574-6968.1999.tb13519.x
Djukic, M., Erler, S., Leimbach, A., Grossar, D., Charrière, J.-D., Gauthier, L., ... Daniel, R. (2018). Comparative genomics and description of putative virulence factors of Melissococcus p/utonius, the causative agent of European foulbrood disease in honey bees. Genes, 9(8), 419. https://doi.org/10.3390/genes9080419

Doughty, S., Luck, J., \& Goodman, R. (2004). Evaluating alternative antibiotics for control of European Foulbrood disease. Rural Industries Research and Development Corporation.

Evans, J. D. (2003). Diverse origins of tetracycline resistance in the honey bee bacterial pathogen Paenibacillus larvae. Journal of invertebrate Pathology, 83(1), 46-50. https://doi.org/10.1016/s00222011(03)00039-9

Flores, I., Spivak, M., \& Gutiérrez, I. (2005). Spores of Ascosphaera apis contained in wax foundation can infect honeybee brood. Veterinary microbiology, 108(1-2), 141-144. https://doi.org/10.1016/j.vetmic.2005.03.005

Fontana, R., Mendes, M. A., De Souza, B. M., Konno, K., César, L. M. M., Malaspina, O., \& Palma, M. S. (2004). Jelleines: a family of antimicrobial peptides from the Royal Jelly of honeybees (Apis mellifera). Peptides, 25(6), 919-928. https://doi.org/10.1016/j.peptides.2004.03.016

Forsgren, E. (2010). European foulbrood in honey bees. Journal of Invertebrate Pathology, 103, S5-S9. https://doi.org/10.1016/j.jp.2009.06.016

Forsgren, E., Budge, G. E., Charrière, J.-D., \& Hornitzky, M. A. (2013). Standard methods for European foulbrood research. Journal of Apicultural Research, 52(1), 1-14. https://doi.org/10.3896/IBRA.1.52.1.12

Forsgren, E., Locke, B., Sircoulomb, F., \& Schäfer, M. O. (2018). Bacterial Diseases in Honeybees. Current Clinical Microbiology Reports, 5(1), 18-25. https://doi. org/10.1007/s40588-018-0083-0

Forsgren, E., Lundhagen, A. C., Imdorf, A., \& Fries, I. (2005). Distribution of Melissococcus plutonius in honeybee colonies with and without symptoms of 


\section{— DE IEÉW-DOOH Ee Hl. ___ Pathogenesis of Melissococcus p/utonius}

European foulbrood. Microbial Ecology, 50(3), 369374. https://doi.org/10.2307/25153260

Garrido-Bailón, E., Higes, M., Martínez-Salvador, A., Antúnez, K., Botías, C., Meana, A., . . . MartínHernández, R. (2013). The prevalence of the honeybee brood pathogens Ascosphaera apis, Paenibacillus larvae and Melissococcus plutonius in Spanish apiaries determined with a new multiplex PCR assay. Microbial Biotechnology, 6(6), 731-739. https://doi.org/10.1111/1751-7915.12070

Genersch, E. (2010). American Foulbrood in honeybees and its causative agent, Paenibacillus larvae. Journal of Invertebrate Pathology, 103, S10-S19. https://doi.org/10.1016/j.jip.2009.06.015

Giersch, T., Barchia, I., \& Hornitzky, M. (2010). Can fatty acids and oxytetracycline protect artificially raised larvae from developing European foulbrood? Apidologie, 47(2), 151-159. https://doi.org/10.1051/ apido/2009066

Gochnauer, T., Furgala, B., \& Shimanuki, H. (1975). Diseases and enemies of the honey bee. Hive and the Honey Bee, 615-621. http://agris.fao.org/agrissearch/search.do?recordID=US201302483835

Goodwin, R. M., Perry, J. H., \& Houten, A. T. (1994). The effect of drifting honey bees on the spread of American foulbrood infections. Journal of Apicultural Research, 33(4), 209-212. https://doi.org/10.1080/0 0218839.1994 .11100873

Hashish, M. E., Khattaby, A. M., Khattab, M. M., Gaaboub, I. A., Omar, R. E. (2016). An in vitro evaluation of Cinnamon (Cinnamomum spp.) and Siwak (Salvadora persica) extracts for controlling the foulbrood pathogens of honeybee. African Journal of Microbiology Research, 10(35), 1483-1493. https://doi. org/10.5897/AJMR2016.8025

Haynes, E., Helgason, T., Young, J. P. W., Thwaites, R., Budge, G. E. (2013). A typing scheme for the honeybee pathogen Melissococcus plutonius allows detection of disease transmission events and a study of the distribution of variants. Environmental Microbiology Reports, 5(4), 525-529. https://doi. org/10.1111/1758-2229.12057

Homan, W. L., Tribe, D., Poznanski, S., Li, M., Hogg, G., Spalburg, E., ... Willems, R. J. (2002). Multilocus sequence typing scheme for Enterococcus faecium. Journal of Clinical Microbiology, 406), 1963-1971. https://doi.org/10.1128/jcm.40.6.1963-1971.2002

Hornitzky, M., \& Smith, L. (1999). Sensitivity of Australian Melissococcus pluton isolates to oxytetracycline hydrochloride. Australian Journal of Experimental Agriculture, 397), 881-883. https://doi. org/10.1071/EA99064

Hornitzky, M. A., \& Smith, L. (1998). Procedures for the culture of Melissococcus pluton from diseased brood and bulk honey samples. Journal of Apicultural Research (United Kingdom). https://doi.org/10.1080/ 00218839.1998.11100987

Killer, J., Dubná, S., Sedláček, I., \& Švec, P. (2014). Lactobacillus apis sp. nov., from the stomach of honeybees (Apis mellifera), having an in vitro inhibitory effect on the causative agents of American and European foulbrood. International Journal of Systematic and Evolutionary Microbiology, 64(1), 152-157. https://doi.org/10.1099/ijs.0.053033-0

Kim, J., Park, S., Shin, Y.-K., Kang, H., Kim, K.-Y. (2018). In vitro antibacterial activity of macelignan and corosolic acid against the bacterial bee pathogens Paenibacillus larvae and Melissococcus plutonius. Acta Veterinaria Brno, 873), 277-284. https://doi. org/10.2754/avb201887030277

Lewkowski, O., \& Erler, S. (2019). Virulence of Melissococcus plutonius and secondary invaders associated with European foulbrood disease of the honey bee. MicrobiologyOpen, 8(3), e00649. https://doi. org/10.1002/mb03.649

Locke, B., Low, M., \& Forsgren, E. (2019). An integrated management strategy to prevent outbreaks and eliminate infection pressure of American foulbrood disease in a commercial beekeeping operation. Preventive Veterinary Medicine, 167,48-52. https://doi. org/10.1016/j.prevetmed.2019.03.023 


\section{ง. APRC. SCLI. VOL. 64 ND. 2 QU20}

Martel, A.-C., Zeggane, S., Drajnudel, P." Faucon, J. P., Aubert, M. (2006). Tetracycline residues in honey after hive treatment. Food Additives and Contaminants, 23(3), 265-273. https://doi. org/10.1080/02652030500469048

Martzy, R., Kolm, C., Brunner, K., Mach, R. L., Krska, R., Šinkovec, H., ... Reischer, G. H. (2017). A loop-mediated isothermal amplification (LAMP) assay for the rapid detection of Enterococcus spp. in water. Water Research, 122, 62-69. https://doi.org/10.1016/j.watres.2017.05.023

McKee, B. A., David Goodman, R., \& Alan Hornitzky, M. (2004). The transmission of European foulbrood (Melissococcus plutonius) to artificially reared honey bee larvae (Apis mellifera). Journal of Apicultural Research, 43(3), 93-100. https://doi.org/10.1080/0021 8839.2004.11101117

McKee, B. A., Djordjevic, S. P., Goodman, R. D., \& Hornitzky, M. A. (2003). The detection of Melissococcus pluton in honey bees (Apis mellifera) and their products using a hemi-nested PCR. Apidologie, 34(1), 1927. https://doi.org/10.1051/apido:2002047

Melliou, E., \& Chinou, I. (2014). Chemistry and bioactivities of royal jelly. Studies in Natural Products Chemistry, 43, 261-290. https://doi.org/10.1016/ B978-0-444-63430-6.00008-4

Moeller, F. (1978). European foulbrood and sacbrood control. American Bee Journal, 311-315.

Morse, R. A., \& Calderone, N. W. (2000). The value of honey bees as pollinators of US crops in 2000. Bee Culture, 128(3), 1-15.

Nakamura, K., Yamazaki, Y., Shiraishi, A., Kobayashi, S., Harada, M., Yoshiyama, M., ... Takamatsu, D. (2016). Virulence Differences among Melissococcus p/utonius Strains with Different Genetic Backgrounds in Apis mellifera Larvae under an Improved Experimental Condition. Scientific Reports, 6. https://doi. org/10.1038/srep33329

Ohashi, K., Natori, S., \& Kubo, T. (1999). Expression of amylase and glucose oxidase in the hypopharyn- geal gland with an age-dependent role change of the worker honeybee (Apis mellifera L.). European Journal of Biochemistry, 265(1), 127-133. https://doi. org/10.1046/j.1432-1327.1999.00696.x

OlE. (2019). The World Organisation for Animal Health Disease distribution maps: European foulbrood of honey bees. Retrieved from: https://www.oie.int/wahis_2/public/wahid.php/ Diseaseinformation/Diseasedistributionmap/index/ newlang/en?disease_type_hidden=0\&disease id_hidden $=123 \&$ selected_disease_name_hi dden=European+foulbrood+of+honey+be es+\%28-+-\%29+\&disease_type=0\&disease_ id_terrestrial $=123 \&$ species_t $=0 \&$ disease_ id_aquatic $=-999 \&$ species_a=0\&sta_ method=semesterly\&selected_start_ year=2019\&selected_report_period=2\&selected_ start_month=1

Okumura, K., Arai, R., Okura, M., Kirikae, T., Takamatsu, D., Osaki, M., Miyoshi-Akiyama, T. (2011). Complete genome sequence of Melissococcus plutonius ATCC 35311. Journal of Bacteriology, 193(15), 4029-4030. https://doi.org/10.1128//B.05151-11

Okumura, K., Arai, R., Okura, M., Kirikae, T., Takamatsu, D., Osaki, M., Miyoshi-Akiyama, T. (2012). Complete genome sequence of Melissococcus plutonius DAT561, a strain that shows an unusual growth profile and is representative of an endemic cluster in Japan. Journal of Bacteriology, 194(11), 3014-3014. https://doi.org/10.1128//B.00437-12

Okumura, K., Takamatsu, D., \& Okura, M. (2018). Complete genome sequence of Melissococcus plutonius DAT561, a strain that shows an unusual growth profile, obtained by PacBio sequencing. Genome Announcements., 6(23), e00431-00418. https://doi. org/10.1128/genomeA.00431-18

Okumura, K., Takamatsu, D., \& Okura, M. (2019). Complete Genome Sequences of Two Melissococcus plutonius Strains with Different Virulence Profiles, Obtained by PacBio Sequencing. Microbiology Resource Announcements, 8(21), e00038-00019. https://doi.org/10.1128/MRA.00038-19 


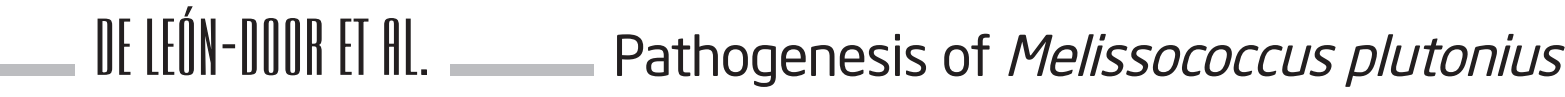

Peng, Y.-S. C., Mussen, E., Fong, A., Montague, M. A., Tyler, T. (1992). Effects of chlortetracycline of honey bee worker larvae reared in vitro. Journal of Invertebrate Pathology, 602), 127-133. https://doi. org/10.1016/0022-2011(92)90085-।

Roetschi, A., Berthoud, H., Kuhn, R., \& Imdorf, A. (2008). Infection rate based on quantitative realtime PCR of Melissococcus plutonius, the causal agent of European foulbrood, in honeybee colonies before and after apiary sanitation. Apidologie, 39(3), 362-371. https://doi.org/10.1051/apido:200819

Ruiz-Garbajosa, P., Bonten, M. J., Robinson, D. A., Top, .., Nallapareddy, S. R., Torres, C., .... Murray, B. E. (2006). Multilocus sequence typing scheme for Enterococcus faecalis reveals hospital-adapted genetic complexes in a background of high rates of recombination. Journal of Clinical Microbiology, 44(6), 2220-2228. https://doi.org/10.1128//CM.02596-05

Sano, O., Kunikata, T., Kohno, K., Iwaki, K., Ikeda, M., Kurimoto, M. (2004). Characterization of royal jelly proteins in both Africanized and European honeybees (Apis mellifera) by two-dimensional gel electrophoresis. Journal of Agricultural and Food Chemistry, 52(1), 15-20. https://doi.org/10.1021/jf030340e

Santos, R. C. V., Lopes, L. Q. S., Alves, C. F. d. S., Fausto, V. P., Pizzutti, K., Barboza, V., ... de Almeida Vaucher, R. (2014). Antimicrobial activity of tea tree oil nanoparticles against American and European foulbrood diseases agents. Journal of Asia-Pacific Entomology, 173), 343-347. https://doi.org/10.1016/j.aspen.2014.02.003

Šedivá, M., Laho, M., Kohútová, L., Mojžišová, A., Majtán, J., Klaudiny, J. (2018). 10-HDA, a major fatty acid of royal jelly, exhibits $\mathrm{pH}$ dependent growthinhibitory activity against different strains of Paenibacillus larvae. Molecules, 23(12), 3236. https://doi. org/10.3390/molecules23123236

Singh Rana, B., Mohan Rao, K., Chakravarty, S. K., Katna, S. (2012). Characterization of Melissococcus plutonius causing European foulbrood disease in Apis cerana F. Journal of Apicultural Research, 57(4), 306-311. https://doi.org/10.3896/IBRA.1.51.4.03
Snodgrass, R. E. (1925). Anatomy and Physiology of the Honeybee: Mcgeaw-Hallbook Company, Ics New York And London.

Spivak, M., Masterman, R., Ross, R., \& Mesce, K. A. (2003). Hygienic behavior in the honey bee (Apis mellifera L.) and the modulatory role of octopamine. Journal of Neurobiology, 55(3), 341-354. https://doi. org/10.1002/neu.10219

Takamatsu, D., Arai, R., Miyoshi-Akiyama, T., Okumura, K., Okura, M., Kirikae, T., ... Osaki, M. (2013). Identification of mutations involved in the requirement of potassium for growth of typical Melissococcus plutonius strains. Applied and Environmental Microbiology, 79(12), 3882-3886. https://doi.org/10.1128/ AEM.00598-13

Takamatsu, D., Morinishi, K., Arai, R., Sakamoto, A., Okura, M., Osaki, M. (2014). Typing of Melissococcus plutonius isolated from European and lapanese honeybees suggests spread of sequence types across borders and between different Apis species. Veterinary Microbiology, 177(1), 221-226. https://doi. org/10.1016/j.vetmic.2014.03.036

Takamatsu, D., Osaki, M., \& Sekizaki, T. (2001). Thermosensitive suicide vectors for gene replacement in Streptococcus suis. Plasmid, 46(2), 140-148. https:// doi.org/10.1006/plas.2001.1532

Takamatsu, D., Osawa, A., Nakamura, K., Yoshiyama, M., Okura, M. (2017). High-level resistance of Melissococcus plutonius clonal complex 3 strains to antimicrobial activity of royal jelly. Environmental Microbiology Reports. https://doi.org/10.1111/17582229.12590

Takamatsu, D., Sato, M., \& Yoshiyama, M. (2016). Infection of Melissococcus plutonius clonal complex 12 strain in European honeybee larvae is essentially confined to the digestive tract. Journal of Veterinary Medica/Science, 78(1), 29-34. https://doi. org/10.1292/jvms.15-0405

Takamatsu, D., Yoshiyama, M., Okura, M., \& Osaki, M. (2015). Application of a thermosensitive suicide vector for Streptococcus to construction of deletion 


\section{ง. APIC. SCLI. VOL. 64 NO. 2 2020}

mutants in Melissococcus plutonius, the causative agent of European foulbrood. Journal of Apicultural Research, 54(2), 96-98. https://doi.org/10.1080/002 18839.2015 .1103996

Tarr, H. (1938). Studies on european foul brood of bees: IV. On the attempted cultivation of Bacillus pluton, the susceptibility of individual larvae to inoculation with this organism and its localization within its host. Annals of Applied Biology, 25(4), 815-821. https://doi.org/10.1111/j.1744-7348.1938.tb02356.x

Tenover, F. C., Arbeit, R. D., Goering, R. V., Mickelsen, P. A., Murray, B. E., Persing, D. H., Swaminathan, B. (1995). Interpreting chromosomal DNA restriction patterns produced by pulsed-field gel electrophoresis: criteria for bacterial strain typing. Journal of Clinical Microbiology, 33(9), 2233.

Thompson, H. M., Waite, R. J., Wilkins, S., Brown, M. A., Bigwood, T., Shaw, M., .. Sharman, M. (2005). Effects of European foulbrood treatment regime on oxytetracycline levels in honey extracted from treated honeybee (Apis mellifera) colonies and toxicity to brood. Food Additives and Contaminants, 22(6), 573-578. https://doi.org/10.1080/02652030500089986

Tibatá, V. M., Junca, H., Sánchez, A., Corona, M., Ariza Botero, F., Figueroa, J. (2018). Molecular detection of Melissococcus plutonius assessed in Africanized honey bee populations (Apis mellifera) in three regions of Colombia. Journal of Apicultural Research, 1-7. https://doi.org/10.1080/00218839.2018.14391 51

Trüper, H. G., \& de'Clari, L. (1998). Taxonomic note: erratum and correction of further specific epithets formed as substantives (nouns)'in apposition.' International Journal of Systematic and Evolutionary Microbiology, 48(2), 615-615. https://doi. org/10.1099/00207713-48-2-615

Vandamme, E. J., \& Mortelmans, K. (2019). A century of bacteriophage research and applications: impacts on biotechnology, health, ecology and the economy! Journal of Chemical Technology \& Biotechnology, 94(2), 323-342. https://doi.org/10.1002/jctb.5810
Vásquez, A., Forsgren, E., Fries, I., Paxton, R. J., Flaberg, E., Szekely, L., Olofsson, T. C. (2012). Symbionts as Major Modulators of Insect Health: Lactic Acid Bacteria and Honeybees. PLOS ONE, 73), e33188. https://doi.org/10.1371/journal.pone.0033188

Vezeteu, T. V., Bobiş, O., Moritz, R. F., \& Buttstedt, A. (2017). Food to some, poison to others-honeybee royal jelly and its growth inhibiting effect on European Foulbrood bacteria. MicrobiologyOpen, 6(1). https://doi.org/10.1002/mbo3.397

von Büren, R. S., Oehen, B., Kuhn, N. J., \& Erler, S. (2019). High-resolution maps of Swiss apiaries and their applicability to study spatial distribution of bacterial honey bee brood diseases. Peer), 7,e6393. https://doi.org/10.7717/peerj.6393

Waite, R. J., Brown, M. A., Thompson, H. M., \& Bew, M. H. (2003). Controlling European foulbrood with the shook swarm method and oxytetracycline in the UK. Apidologie, 34(6), 569-575. https://doi.org/10.1051/ apido:2003052

White, G. F. (1912). The cause of European foul brood (No. 157). US Government Printing Office.

Wiese, N., Fischer, J., Heidler, J., Lewkowski, O., Degenhardt, J., Erler, S. (2018). The terpenes of leaves, pollen, and nectar of thyme (Thymus vulgaris) inhibit growth of bee disease-associated microbes. Scientific Reports, 8(1), 14634. https://doi.org/10.1038/ s41598-018-32849-6

Wilkins, S., Brown, M. A., \& Cuthbertson, A. G. (2007). The incidence of honey bee pests and diseases in England and Wales. Pest Management Science, 63(11), 1062-1068. https://doi.org/10.1002/ps.1461

Wu, M., Sugimura, Y., Iwata, K., Takaya, N., Takamatsu, D., Kobayashi, M., .. Y Yoshiyama, M. (2014). Inhibitory effect of gut bacteria from the Japanese honey bee, Apis cerana japonica, against Melissococcus plutonius, the causal agent of European foulbrood disease. Journal of Insect Science, 14(1). https://doi. org/10.1093/jis/14.1.129 


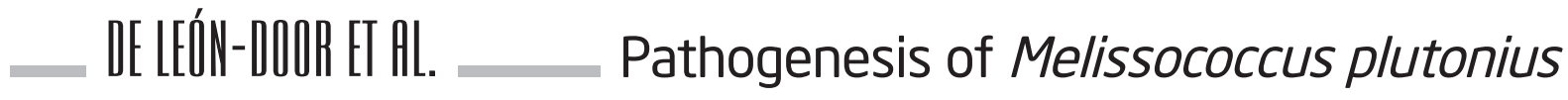

Yang, X., Li, J., \& Wang, R. (2015). Antibacterial Mechanism of 10-HDA Against Bacillus subtilis. Advances in Applied Biotechnology, 332, 317-324. https://doi. org/10.1007/978-3-662-45657-6_34

Yost, D. G., Tsourkas, P., \& Amy, P. S. (2016). Experimental bacteriophage treatment of honeybees (Apis mellifera) infected with Paenibacillus larvae, the causative agent of American Foulbrood disease. Bacteriophage, 6(1), el122698. https://doi.org/10.10 80/21597081.2015.1122698 